\title{
Determination of Trace Metals in Waters by FAAS after Enrichment as Metal-HMDTC Complexes Using Solid Phase Extraction
}

\author{
Şerife Tokahoğlu, Şenol Kartal, and Latif Elçi ${ }^{\dagger}$ \\ Department of Chemistry Ercives Lniversity Factity of Ant and Science, TR-38039, Kavseri, TURKEY \\ -Department of Chemistry, Pamikkale Enversity, Faculty of Art and Science, TR-20020, Denizli, TLRKEY \\ Received September 10,2001
}

\begin{abstract}
A method has been described for the determination of $\mathrm{Cu}(\mathrm{II})$. $\mathrm{Pb}$ (II). Ni(II). $\mathrm{Cd}(\mathrm{II})$. $\mathrm{Mn}$ (II) and Fe(III) by flame atomic absorption spectrometry (FAAS) after preconcentration on Amberlite XAD-16 resin. using hexamethy leneammonium-hexamethy lenedithiocarbamate (HMA-HMDTC) as a chelating agent. and $\mathrm{NH}_{3} /$ $\mathrm{NH}_{4} \mathrm{Cl}$ buffer solution ( $\mathrm{pH}$ 9). Influences of various analytical parameters such as $\mathrm{pH}$. concentration of nitric acid. amount of analytes. diverse ions and sample volume were investigated. The relative standard deviation (RSD) and the detection limit (LOD) were found in the range of $0.8-2.9 \%$ and $0.006-0.277 \mu \mathrm{g} / \mathrm{mL}$. respectively. Recoveries obtained by the column method were quantitative (>95\%) at optimum conditions. The method was applied to the deternination of some metal ions in seawater and wastewater samples. A high preconcentration factor (about 150 for seawater and 75 for wastewater samples) and simplicity are the main advantages of this suggested method.
\end{abstract}

Keywords : Amberlite XAD 16 resin. Preconcentration. Seawater, Wastewater.

\section{Introduction}

Efforts to determine trace metals directly and reliably by flame atomic absorption spectrometry (FAAS) is limited owing to the low concentrations of analytes and matrix interferences. Therefore, separation and enrichment technjques are of great importance in trace metal analysis by modern instrumental methods. To enhance the sensitivity and the precision of the method. preconcentration and separation techniques, ${ }^{1}$ such as coprecipitation. ${ }^{2,3}$ liquid-liquid phase extraction. ${ }^{4,5}$ ion exchange. ${ }^{6.7}$ and recently, solid-phase extraction. ${ }^{\mathrm{s}-11}$ are most frequently used. In the case of the solid-phase extraction, the enrichment of the trace elements with various chelating agents using funely pulverized adsorbent resins of the macroreticular type, has been widely used for the determination of trace metals in different samples associated with various instrunental tecluiques. Among these techniques, FAAS is preferred because it is simple and inexpensive. ${ }^{11}$

In the solid-phase extraction. the synthetic adsorbent resins. especially Amberlite XAD series (XAD-2, -4, -7. -8. - 16 . and -1180 etc.), have been widely used to enrich trace elements from aqueous solutions. ${ }^{12.13}$ of the Amberlite XAD series adsorbents. Amberlite XAD-16 resin exhibits the highest surface area $\left(825 \mathrm{~m}^{2} \mathrm{~g}^{-1}\right)$ and is a nonionic polymeric adsorbent. Therefore, the Amberlite XAD-16 was selected for our experiments.

Dithiocarbamates, such as sodium diethyldithiocarbamate (DDC) and ammonium pyrrolidinedithiocarbantate (APDC), have been widely used as chelating agents for the separation. preconcentration and determination of trace metals because of their thermodynamically stable metal complexes. ${ }^{14.15}$

Corresponding author: e-mail: serifet ầerciyes.edu.tr
Dithiocarbamate compounds have sulfur atoms as electrondonor in their structures. Uncharged chelates form when metal ions react with bifunctional ligands. such as dithiocarbamates. dithizone, oxine etc. Metals that give sparinglysoluble sulphides can be extracted as complexes with ligands that bond through sulphur atoms, e.g. dithizone and dithiocarbamates. ${ }^{16}$ Also. the high molar absorptivities of metal dithiocarbamate complexes make them useful spectrophotometric reagents for trace metal analy ses. So far, HMAHMDTC. a dithiocarbamate compound. has been mainly used for the preconcentration of trace metals with various methods. ${ }^{4,17}$ However. HMA-HMDTC has not been used frequently in analytical chemistry compared with the other dithiocarbamates. In recent years a few papers conceming the determination of metal ions in different media or various samples by using HMA-HMDTC have been published, touting this compound in various methods. such as coprecipitation. ${ }^{18}$ solvent extraction, ${ }^{4.19 .21}$ and more extensively as a precipitate collector in colloid flotation tecluique ${ }^{21.27}$ At the same time. HMA-HMDTC is a suitable chelating agent for ligh-performance liquid clromatography (HPLC) of metal complexes, because the metal-HMDTC complexes are more stable in the eluents of the reversed-phase HPLC. ${ }^{17}$

The present paper deals with a separation and enrichment of some heavy metals by means of metal-HMDTC complexes and solid-phase. In this study. a column packed with Amberlite XAD-16 resin was used to separate and preconcentrate trace metals. The influences arising from $\mathrm{pH}$, nitric acid concentration. amount of analytes, diverse ions, and sample volume on the recoveries were assessed. The procedure was successfully employed for the determination of the trace metals in the seawater and wastewater samples by FAAS. 


\section{Experimental Section}

Instrument and chemicals. A Hitachi Z-8000 model atomic absorption spectrometer (Hitachi, Japan) with an air/ acetylene flame and a Zeeman background corrector was used to detennine of the metal ions in model solutions and in the water samples. The operating conditions suggested in the instrument data processor were followed. ${ }^{2 s}$ All the $\mathrm{pH}$ measurements were made by means of a Nel digital $\mathrm{pH}$ meter (Nel Co. Turkey) with a combinated $\mathrm{pH}$ electrode.

Analytical reagent grade chemicals (Merck. Darmstadt, Germany) and doubly distilled water obtained by using a quartz apparatus were used. A stock solution of $1000 \mu \mathrm{g} / \mathrm{mL}$ in $1 \mathrm{M} \mathrm{HNO}_{3}$ for each element interested was prepared from the corresponding nitrate salt. The standard working solutions were prepared by diluting the stock solutions when necessary. A stock solution of HMA-HMDTC $(0.1 \%, w / v)$ was prepared daily by dissolving $0.1 \mathrm{~g}$ of HMA-HMDTC in ethyl alcohol (stored in a dark bottle to protect from light) and diluted to $\mathrm{I} \times 10^{-5} \mathrm{M}$ for the experiments. To avoid any contamination. all glassware were treated by soaking in concentrated nitric acid ( $1: 1 . v / v)$ for 24 hours and then rinsing with distilled water. The ammonia-ammonium chloride buffer solutions were used to adjust the $\mathrm{pH}$ of the solutions in the range of $\mathrm{pH} 8-10$

Sampling of seawater and wastewater. The seawater samples were taken from the Amasra Bay. in Zonguldak province of Turkey, on the South-West terrestrial basin of the Black Sea. The wastewater samples were collected from the Karasu stream in August 2000. which includes all municipal and industrial wastes of Kayseri province before reaching the wastewater treatment plant. in Kayseri province in Central Anatolian of Turkey. The samples were in sin acidified to $\mathrm{pH} \mathrm{I}$ and then filtered through a Nuclepore cellulose membrane filter with a pore size of $0.45 \mu \mathrm{m}$, and stored in a refrigerator at $4{ }^{\circ} \mathrm{C}$ until the analy sis. ${ }^{29}$

Column preparation. Amberlite XAD-16 resin (wet mesh size 20-50, Rohn and Haas Co.) was pulverized and sieved to 70-140 mesh. Pulverization increases the total surface area of the resin. which comes into contact with aqueous sample solution. ${ }^{30}$ It was used after being washed with methanol. $1 \mathrm{M} \mathrm{HNO}_{3}$ in acetone. water. $1 \mathrm{M} \mathrm{NaOH}$, water. and acetone, respectively and dried for an hour at $100^{\circ} \mathrm{C}$. A 400-mg of Amberlite XAD-16 resin suspended in water was packed into a glass column $(10 \mathrm{~mm}$ i.d. $\times 100 \mathrm{~mm}$ height).

Procedure. Some preliminary studies were performed to determine the trace metals in water samples after preconcentration onto the column filled with Amberlite XAD16 resin. For this purpose. to the model solutions of $25 \mathrm{~mL}$ including the trace metals (Cd(II) and $\mathrm{Mn}$ (II) $2.5 \mu \mathrm{g}$ : $\mathrm{Cu}$ (II). $\mathrm{Co}$ (II) and $\mathrm{Ni}$ (II) $5 \mu \mathrm{g}$ : $\mathrm{Fe}$ (III) and $\mathrm{Cr}$ (III) $10 \mu \mathrm{g}: \mathrm{Pb}$ (II) and $\mathrm{Bi}(\mathrm{III}) 20 \mu \mathrm{g}$ ). $1 \mathrm{~mL}$ of $\mathrm{NH}_{3} / \mathrm{NH}_{4} \mathrm{Cl}$ buffer ( $\mathrm{pH} 9.0$ ) and the HMA-HMDTC reagent $\left(1 \times 10^{-5} \mathrm{M}\right.$, in initial solution of 25 $\mathrm{mL}$ ) to form metal-HMDTC complexes. formed in model solutions before entering the column. were added. The resin was preconditioned with $2-3 \mathrm{~mL}$ of a blank solution contain- ing the HMA-HMDTC reagent. which was diluted ten fold according to the working solutions and $\mathrm{NH}_{2} / \mathrm{NH}_{4} \mathrm{Cl}$ buffer solution ( $\mathrm{pH}$ 9.0). The model solutions ( $\mathrm{pH} 9.0$ ) containing metal-HMDTC complexes were introduced carefully to the column and then passed through the column at a flow rate of 2.0-2.5 $\mathrm{mL} / \mathrm{min}$ by using a vacuum pump. The metalHMDTC complexes retained on the column were eluted with $1 \mathrm{M} \mathrm{HCl}$ in acetone at a flow rate of $1 \mathrm{~mL} / \mathrm{min}$. Sample and eluent flow rates are important parameters to obtain quantitative retention and elution, respectively. After eluting. the concentrated solution obtained was evaporated near to dryness and then the residue was completed to $5 \mathrm{~mL}$ with 1 $\mathrm{M} \mathrm{HCl}$. The metal ions in this solution were detemined by FAAS. After the elution procedure. the column was prepared by washing with acetone and water. respectively, for reusing. ${ }^{12}$

Preconcentration of trace metal ions from seawater and wastewater samples. An aliquot of $300 \mathrm{~mL}$ of seawater sample and of $150 \mathrm{~mL}$ of wastewater sample were used. The acidified samples were neutralized with $6 \mathrm{M} \mathrm{NaOH}$ and buffered to $\mathrm{pH} 9$ with buffer $\mathrm{NH}_{2} / \mathrm{NH}_{4} \mathrm{Cl}$, and then a sufficient aliquot of stock dithiocarbamate solution $(0.1 \%$, w/y) was added in which the reagent concentration was $1 \times 10^{-5} \mathrm{M}$ in the initial sample solution. The mentioned preconcentration procedure above was applied to the prepared sample solutions. The funal volumes of the seawater and wastewater samples for measuring by FAAS were completed to $2 \mathrm{~mL}$. The concentrations of the elements were determined by the injection method. ${ }^{12}$ using an aliquot of $100 \mu \mathrm{L}$ of these solutions.

\section{Results and Discussion}

Effect of reagent amount. A separation-preconcentration procedure was applied to $500 \mathrm{~mL}$ of model solution buffered with $\mathrm{NH}_{2} / \mathrm{NH}_{4} \mathrm{Cl}$ and not containing the reagent. Only $\mathrm{Cr}$ (III). $\mathrm{Pb}$ (II) and $\mathrm{Fe}(\mathrm{III})$ were quantitatively recovered. Probably, these metals are retained on the resin in hydroxide forms. On the other hand. in the model solutions of $500 \mathrm{~mL}$. containing $1 \times 10^{-6} \mathrm{M}$ reagent the recoveries for $\mathrm{Cd}(\mathrm{II}) . \mathrm{Mn}(\mathrm{II}), \mathrm{Co}$ (II). $\mathrm{Bi}(\mathrm{III})$ and $\mathrm{Ni}$ (II) also increased to some extent. Cu(II) in addition to $\mathrm{Cr}(\mathrm{III}), \mathrm{Pb}$ (II) and $\mathrm{Fe}(\mathrm{III})$ was quantitatively recovered. In the light of these results. the concentration of the reagent added to the model solutions. including the $\mathrm{NH}_{3} /$ $\mathrm{NH}_{4} \mathrm{Cl}$ buffer and the traces. was increased ten fold (up to $\left.1 \times 10^{-5} \mathrm{M}\right)$, as the recovery for some metals ( $\mathrm{Cu} . \mathrm{Cr}$ and $\mathrm{Bi}$ ) decrease when the reagent concentration was lower than $1 \times 10^{-5} \mathrm{M}$. Therefore. the concentration of the reagent in the model solutions was used to be $1 \times 10^{-5} \mathrm{M}$.

Effect of $\mathrm{pH}$ and concentration of nitric acid. One of the most crucial parameters affecting the preconcentration procedure is the $\mathrm{pH}$ of the solution, because the formation of soluble metal-complexes and their stabilities in aqueous solutions are strongly related to the $\mathrm{pH}$ of the medium. Therefore an appropriate volume of the $\mathrm{NH}_{2}-\mathrm{NH}_{4} \mathrm{Cl}$ buffer solutions in which the $\mathrm{pH}$ values were between 8 and 10 changing with intervals of a $0.5 \mathrm{pH}$ unit. was added to the 


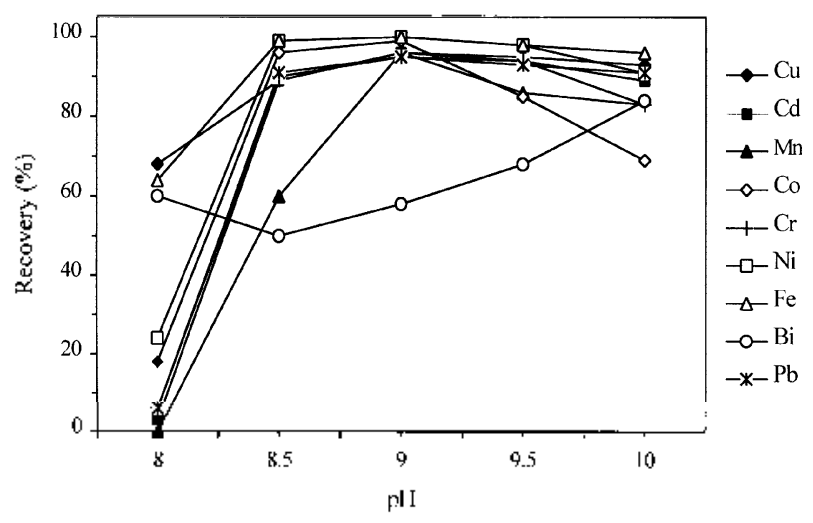

Figure 1. I:llect of $\mathrm{pH}$ on the recoveries (\%) of the elements.

model solutions containing the trace metal ions (Cd(II) and $\mathrm{Mn}(1 \mathrm{l}), 2.5 \mu \mathrm{g} ; \mathrm{Cu}(\mathrm{Il}), \mathrm{Co}(\mathrm{II})$ and $\mathrm{Ni}(\mathrm{II}), 5 \mu \mathrm{g}$ : $\mathrm{Cr}$ (III) and $\mathrm{Fe}(\mathrm{III}), 10 \mu \mathrm{g} ; \mathrm{Pb}(\mathrm{Il})$ and $\mathrm{Bi}(\mathrm{II}), 20 \mu \mathrm{g})$ and the HMAHMDTC, $1 \times 10^{-5} \mathrm{M}$. Because of the recoveries $(\%)$ being measured quantitatively for all the elements, except for $\mathrm{Bi}$, the $\mathrm{pH}$ was chosen as 9.0. The analytical results obtained after applying the separation-preconcentration procedure to the model solutions are illustrated in Figure 1.

The effect of nitric acid concentration $\left(1 \times 10^{-3} \sim 1.0 \mathrm{M}\right)$ on the enrichment procedure was examined in a medium containing the trace metal ions and the complexing agent. As can be seen from Figure 2, the recoveries were quantitative in the range of $1 \times 10^{-3} \sim 1.0 \mathrm{M} \mathrm{HNO}$, for $\mathrm{Cu}(\mathrm{ll}), 60.01 \mathrm{M}$ $\mathrm{HNO}_{3}$ for $\mathrm{Cd}(\mathrm{II})$ and $\mathrm{Pb}(\mathrm{Il}), \leq 0.1 \mathrm{M} \mathrm{HNO}_{3}$ for $\mathrm{Ni}(\mathrm{ll})$. With a concentration of $\mathrm{HNO}_{3}$ higher than $1 \times 10^{-2} \mathrm{M}$, the recovery for $\mathrm{Bi}(1 \mathrm{ll})$ was quantitative. Because $\mathrm{Bi}(\mathrm{III})$ may undergo hydrolysis or form oxycation at $\mathrm{pH}$ values above 2 . In addition, the recoveries were not quantitative for $\mathrm{Mn}$ (II) and $\operatorname{Cr}(I I I)(<5 \%), \operatorname{Co}(I I)(\leq 42 \%)$, and $\mathrm{Fe}(\mathrm{III})(\leq 85 \%)$ for all the $\mathrm{HNO}_{3}$ concentrations. At high concentrations of $\mathrm{HNO}_{3}$, recoveries for Fe and Co may probably decrease due to the decomposition of $\mathrm{Fe}(\mathrm{HMDTC})_{3}$ and $\mathrm{Co}(\mathrm{HMDTC})_{2}$ complexes andior their low stabilities. When the $\mathrm{pH}$ of the medium was adjusted with $\mathrm{HNO}_{3}$, the number of recovered elements was lower than those of the $\mathrm{NH}_{3} / \mathrm{NH}_{+} \mathrm{Cl}$ buffer

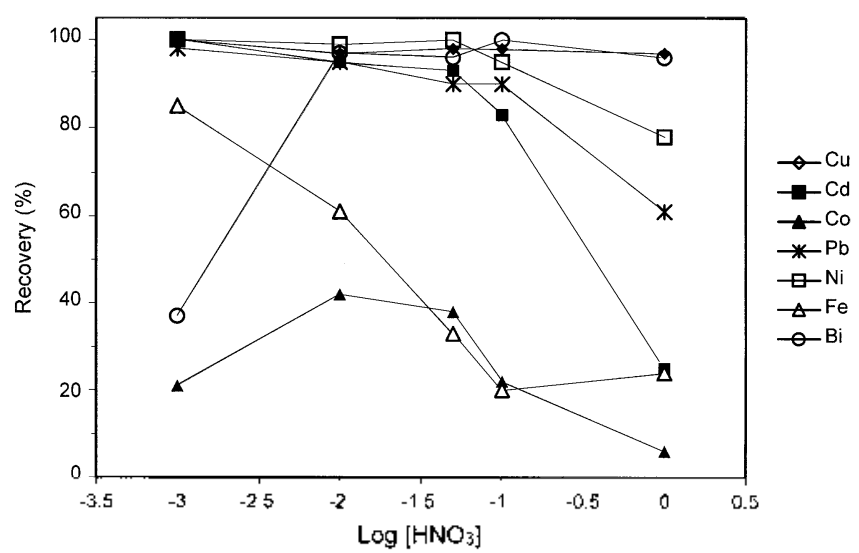

Figure 2. Variation of the recovery values $(\%)$ with the concentration of nitric acid. medium. Because of this, the $\mathrm{pH}$ of the working medium was chosen to be 9.0 by means of $\mathrm{NH}_{3} / \mathrm{NH}_{4} \mathrm{Cl}$ buffer solution.

Fffect of sample volume. In the analysis of a real sample using preconcentration, the sample volume is one of the important parameters for obtaining high concentration factors. Therefore, the effects of sample volume on the retention behavior of the analytes examined were studied by varying the volume from 100 to $1000 \mathrm{ml}$, prepared using a medium containing the buffer solution $(\mathrm{pH} 9.0)$ and the reagent. $1 \times 10^{-5} \mathrm{M}$. The effect of the sample volume between 100 and $1000 \mathrm{ml}$, on the recoveries of the elements was examined and the results are shown in Figure 3. As can be seen, $\mathrm{Cu}(\mathrm{II})$ and $\mathrm{Pb}(\mathrm{II})$ up to $500 \mathrm{~mL}, \mathrm{Mn}(\mathrm{II})$ up to $700 \mathrm{~mL}$. and $\mathrm{Fe}(\mathrm{III}), \mathrm{Ni}(\mathrm{II})$ and $\mathrm{Cd}(\mathrm{II})$ up to $1000 \mathrm{~mL}$. were quantitatively recovered, except for $\mathrm{Cr}(\mathrm{II})$ and $\mathrm{Bi}(\mathrm{Il})$. The recovery value of $\mathrm{Co}(\mathrm{II})$ was $28 \%$ for $100 \mathrm{ml}$. of the model solution. and therefore, Co(II) was not determined in the seawater and wastewater samples.

Effect of analyte amount. To determine the influence of the analyte amounts on the recoveries, model solutions of 25 $\mathrm{ml}$. including $\mathrm{NH}_{3} \mathrm{NH}_{1} \mathrm{Cl}$ buffer, the reagent $\left(1 \times 10^{-5} \mathrm{M}\right)$ and increasing amounts of the trace elements $(1-40 \mu \mathrm{g}$, in a final solution of $5 \mathrm{ml}$.) were prepared. The enrichment procedure was performed by using the column packed with $400 \mathrm{mg}$ of Amberlite XAD-16 resin, and the results are given in Table 1. The recoveries were not quantitative for $\mathrm{Mn}(\mathrm{II})$ and $\mathrm{Cd}(\mathrm{II})$ when their amounts were higher than 10 and $20 \mu \mathrm{g}$, respectively, However, the recoveries for $\mathrm{Cu}(11)$. $\mathrm{Cr}([\mathrm{II}), \mathrm{Pb}(\mathrm{Il}), \mathrm{Ni}(\mathrm{II})$ and $\mathrm{Fe}(\mathrm{III})$ were quantitative for amounts of $1-40 \mu \mathrm{g}$.

Effect of foreign ions. The model solutions, taking into consideration levels of the main concomitant ions, such as $\mathrm{Ca}(\mathrm{II}), \mathrm{Mg}(\mathrm{II}), \mathrm{Na}^{-}, \mathrm{K}^{+}, \mathrm{Cl}^{-}$and $\mathrm{SO}_{1}{ }^{2-}$, present in seawater and wastewater samples, were prepared to evaluate the matrix effects on analytical signals of the traces. For this purpose, the model solutions containing $2.5 \mu \mathrm{g}$ for $\mathrm{Cd}(\mathrm{Il})$ and $\mathrm{Mn}(\mathrm{II}) ; 5 \mu \mathrm{g}$ for $\mathrm{Cu}(\mathrm{II}), \mathrm{Ni}(\mathrm{II})$, and $\mathrm{Co}(\mathrm{II}) ; 10 \mu \mathrm{g}$ for $\mathrm{Fe}(\mathrm{III})$ and $\mathrm{Cr}(\mathrm{III})$, and $20 \mu \mathrm{g}$ for $\mathrm{Pb}(\mathrm{II})$ and $\mathrm{Bi}$ (III), plus concomitant ions $\left(100-5000 \mu \mathrm{g} / \mathrm{mL} \mathrm{K}^{-} ; 10-40000 \mu \mathrm{g} / \mathrm{mL}\right.$ $\mathrm{Na}^{-}$and also up to about $61700 \mu \mathrm{g} / \mathrm{mL} \mathrm{Cl}^{-}$ion: $10-5000 \mu \mathrm{g} /$

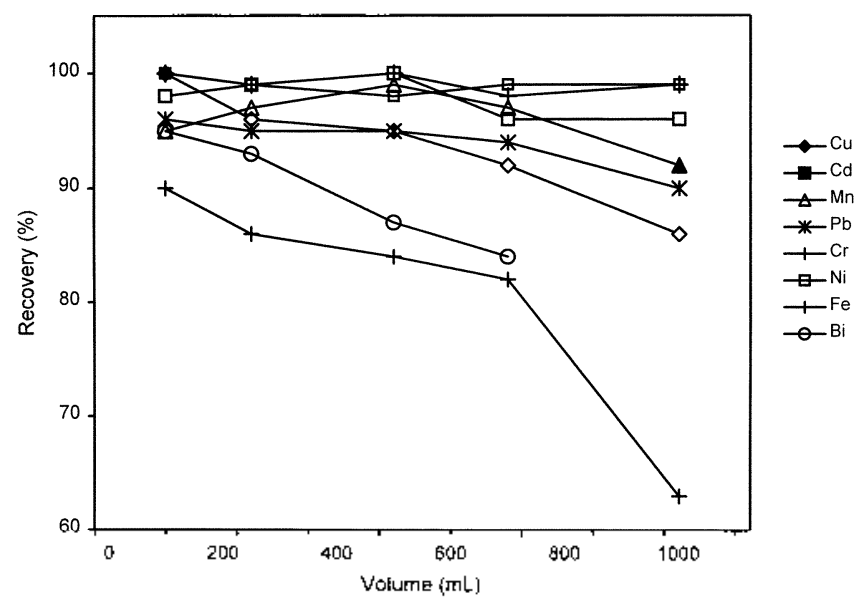

Figure 3. Variation of the recoveries (\%) with the sample volume. 
Table 1. Variation of the recoveries with increasing amounts of the elements in a medium containing $\mathrm{NH}_{3} / \mathrm{NH}_{4} \mathrm{Cl}$ buffer $(\mathrm{pH}$ 9) and HMA-HMDTC reagent $\left(1 \times 10^{-5} \mathrm{M}\right)$

\begin{tabular}{cccccccc}
\hline \multirow{2}{*}{$\begin{array}{c}\text { Amount of } \\
\text { element, } \mu \mathrm{g}\end{array}$} & $\mathrm{Cu( \textrm {II } )}$ & $\mathrm{Cd}(\mathrm{II})$ & $\mathrm{Mn}(\mathrm{II})$ & $\mathrm{Cr}(\mathrm{III})$ & $\mathrm{Pb}(\mathrm{II})$ & $\mathrm{Ni}(\mathrm{II})$ & $\mathrm{Fe}(\mathrm{III})$ \\
\hline 1 & 100 & 97 & 95 & 96 & 97 & 100 & 96 \\
2 & 98 & 97 & 94 & 97 & 95 & 99 & 95 \\
10 & 95 & 96 & 92 & 95 & 96 & 97 & 95 \\
20 & 93 & 95 & 90 & 94 & 94 & 98 & 94 \\
40 & 93 & 72 & 83 & 93 & 93 & 99 & 95 \\
\hline
\end{tabular}

$\mathrm{mL} \mathrm{Ca}(\mathrm{II})$ and $\mathrm{Mg}(\mathrm{II}) ; 100-200 \mu \mathrm{g} / \mathrm{mL} \quad \mathrm{SO}_{4}{ }^{{ }^{-}}$) were prepared. The results acquired by using the model solutions buffered with $\mathrm{NH}_{3} / \mathrm{NH}_{4} \mathrm{Cl}$ and including the reagent, analytes, and concomitants, are shown in Table 2 Quantitative recovery values of the elements after the preconcentration procedure were barely affected by the concomitants ( $\mathrm{Ca}(\mathrm{II}), \mathrm{Mg}(\mathrm{II})$ and $\mathrm{Na}^{-}$). However. the recoveries were quantitative only for the concentrations of matrix ions are less or equal to $500 \mathrm{mg} / \mathrm{mL} \mathrm{K}^{-}$for $\mathrm{Ni}$ (II). $1000 \mathrm{mg} / \mathrm{mL} \mathrm{K}^{+}$for $\mathrm{Fe}$ (III), and $100 \mathrm{mg} / \mathrm{mL} \mathrm{SO}_{4}{ }^{2-}$ for $\mathrm{Pb}$ (II) and $\mathrm{Ni}$ (II). Stated in another way. a large portion of the matrix components passed through the column without retention. The low levels of matrix ions in the eluate solution are of great importance in the determination of the trace metals tested, because their interfering effects are small when they exist in low levels in the funal solution. The results obtained from these experiments (Table 2) demonstrate that the presence of large amounts of alkali and alka-

Table 2. Interfering effects of various matrix components on the determination of the trace metals in the model solutions $(\mathrm{n}=3$ )

\begin{tabular}{|c|c|c|c|c|c|c|c|c|c|}
\hline \multirow{2}{*}{\multicolumn{2}{|c|}{$\begin{array}{l}\text { Metal ions, } \\
\mu g / 11 L\end{array}$}} & \multirow{3}{*}{$\begin{array}{c}\text { In eluate, } \\
\mu \mathrm{g} / 11 \mathrm{~L}\end{array}$} & \multicolumn{7}{|c|}{ Recovery (\%) } \\
\hline & & & \multirow{2}{*}{$\frac{\mathrm{Cd}(\mathrm{II})^{4}}{99}$} & \multirow{2}{*}{$\frac{\mathrm{Cu}(\mathrm{II})^{b}}{98}$} & \multirow{2}{*}{$\frac{\operatorname{Mn}(\mathrm{II})^{a}}{99}$} & \multirow{2}{*}{$\frac{\mathrm{Pb}(\mathrm{II})^{\mathrm{c}}}{99}$} & \multirow{2}{*}{$\frac{C_{r}(\Pi I)^{d}}{98}$} & \multirow{2}{*}{$\frac{\mathrm{Ni}(\mathrm{I})^{4}}{100}$} & \multirow{2}{*}{$\frac{\mathrm{Fe}(\mathrm{II})^{7}}{99}$} \\
\hline $\mathrm{Na}^{-}$ & - & & & & & & & & \\
\hline \multirow[t]{9}{*}{$(\mathrm{NaCl})$} & 10 & 1.03 & 100 & 99 & 99 & 99 & 98 & 99 & 98 \\
\hline & 50 & 6.0 & 99 & 97 & 97 & 98 & 96 & 100 & 100 \\
\hline & 100 & 7.6 & 97 & 98 & 96 & 97 & 96 & 99 & 99 \\
\hline & 250 & 9.8 & 98 & 97 & 96 & 99 & 95 & 95 & 98 \\
\hline & 500 & 28.5 & 95 & 96 & 97 & 96 & 96 & 96 & 99 \\
\hline & 1000 & 47.5 & 97 & 96 & 96 & 95 & 97 & 96 & 100 \\
\hline & 10000 & 56 & 99 & 100 & 98 & 95 & 98 & 100 & 98 \\
\hline & 20000 & 65.5 & 98 & 97 & 96 & 96 & 97 & 100 & 99 \\
\hline & 40000 & 140 & 100 & 97 & 98 & 98 & 99 & 97 & 100 \\
\hline \multirow{8}{*}{$\begin{array}{l}\mathrm{Ca}(\mathrm{II}) \\
{\left[\mathrm{Ca}\left(\mathrm{NO}_{3}\right)_{2}\right]}\end{array}$} & - & - & 99 & 98 & 99 & 99 & 98 & 100 & 99 \\
\hline & 10 & 1.25 & 100 & 99 & 99 & 97 & 99 & 100 & 99 \\
\hline & 50 & 3.23 & 98 & 98 & 98 & 96 & 98 & 99 & 98 \\
\hline & 100 & 4.98 & 99 & 98 & 96 & 96 & 98 & 99 & 100 \\
\hline & 250 & 21.4 & 97 & 96 & 97 & 95 & 97 & 98 & 99 \\
\hline & 500 & 27.7 & 100 & 97 & 96 & 95 & 96 & 100 & 100 \\
\hline & 1000 & 40.6 & 100 & 100 & 97 & 93 & 95 & 100 & 98 \\
\hline & 5000 & 30.0 & 99 & 94 & 99 & 92 & 96 & 98 & 98 \\
\hline \multirow{8}{*}{$\begin{array}{l}\mathrm{Mg}(\mathrm{II}) \\
\left(\mathrm{MgCl}_{2}\right)\end{array}$} & - & - & 99 & 98 & 99 & 99 & 98 & 100 & 99 \\
\hline & 25 & 2.4 & 98 & 99 & 97 & 98 & 99 & 100 & 100 \\
\hline & 50 & 4.7 & 97 & 98 & 95 & 96 & 96 & 99 & 97 \\
\hline & 100 & 6.2 & 97 & 96 & 96 & 95 & 95 & 98 & 99 \\
\hline & 250 & 21.7 & 98 & 97 & 95 & 95 & 95 & 99 & 96 \\
\hline & 500 & 22.0 & 97 & 96 & 96 & 94 & 94 & 100 & 98 \\
\hline & 1000 & 19.7 & 98 & 98 & 95 & 93 & 92 & 99 & 98 \\
\hline & 5000 & 37.3 & 100 & 99 & 97 & 89 & 93 & 100 & 100 \\
\hline \multirow{6}{*}{$\begin{array}{l}\mathrm{K}^{-} \\
(\mathrm{KCl})\end{array}$} & - & - & 99 & 98 & 99 & 99 & 98 & 100 & 99 \\
\hline & 100 & 0.58 & 99 & 98 & 89 & 99 & 99 & 98 & 99 \\
\hline & 250 & 1.53 & 101 & 95 & 98 & 98 & 98 & 100 & 97 \\
\hline & 500 & 3.2 & 99 & 97 & 96 & 97 & 99 & 97 & 98 \\
\hline & 1000 & 5.5 & 101 & 96 & 97 & 97 & 97 & 115 & 103 \\
\hline & 5000 & 21.0 & 107 & 96 & 105 & 99 & 102 & 117 & 115 \\
\hline \multirow{3}{*}{$\begin{array}{l}\mathrm{SO}_{4}{ }^{--} \\
\left(\mathrm{Na}_{2} \mathrm{SO}_{4}\right)\end{array}$} & - & - & 99 & 98 & 99 & 99 & 98 & 100 & 99 \\
\hline & 100 & - & 102 & 98 & 101 & 97 & 103 & 100 & 105 \\
\hline & 200 & - & 99 & 95 & 95 & 86 & 93 & 112 & 103 \\
\hline
\end{tabular}

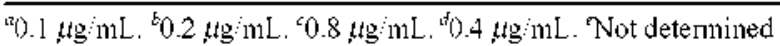


Table 3. Relevant regression results for the calibration graph, detection limit and precision

\begin{tabular}{cccccc}
\hline Element & $\begin{array}{c}R \pm t \cdot s / \sqrt{n} \\
(\%)^{\alpha}\end{array}$ & $\begin{array}{c}\text { RSD\% } \\
(11=10)\end{array}$ & $\begin{array}{c}\text { LOD } \\
\mu g / \mathrm{mL}(11=20)\end{array}$ & Regression equation & Correlation coefficient \\
\hline $\mathrm{Cu}(\mathrm{II})$ & $98 \pm 1.4$ & 1.9 & 0.006 & $\mathrm{~A}=0.0002+0.01362 \cdot \mathrm{C}$ & 0.9999 \\
$\mathrm{Cd}(\mathrm{II})$ & $99 \pm 0.5$ & 1.4 & 0.009 & $\mathrm{~A}=0.0004+0.07+26 \cdot \mathrm{C}$ & 0.9999 \\
$\mathrm{Mn}(\mathrm{II})$ & $99 \pm 0.6$ & 1.7 & 0.019 & $\mathrm{~A}=-0.0002+0.04676 \cdot \mathrm{C}$ & 1.0000 \\
$\mathrm{~Pb}(\mathrm{II})$ & $99 \pm 2.2$ & 2.9 & 0.034 & $\mathrm{~A}=0.0003+0.00594 \cdot \mathrm{C}$ & 0.9999 \\
$\mathrm{Cr}(\mathrm{III})$ & $98 \pm 1.0$ & 0.8 & 0.016 & $\mathrm{~A}=0.0004+0.00971 \cdot \mathrm{C}$ & 0.9995 \\
$\mathrm{Ni}(\mathrm{II})$ & $100 \pm 0.9$ & 1.3 & 0.101 & $\mathrm{~A}=0.0013+0.01906 \cdot \mathrm{C}$ & 0.9995 \\
$\mathrm{Fe}(\mathrm{III})$ & $99 \pm 2.0$ & 1.4 & 0.140 & $\mathrm{~A}=0.0012+0.02456 \cdot \mathrm{C}$ & 0.9998 \\
$\mathrm{Co}(\mathrm{II})$ & - & - & 0.025 & $\mathrm{~A}=0.0006+0.02150 \cdot \mathrm{C}$ & 0.0999 \\
$\mathrm{Bi}(\mathrm{III})$ & - & - & 0.277 & $\mathrm{~A}=0.0014+0.00422 \cdot \mathrm{C}$ & 0.0984 \\
\hline
\end{tabular}

"P $=0.95 .{ }^{\mathrm{r}}(\mathrm{n}=20,3 \mathrm{~s})$. A: Absorbance. C: Concentration ( $\left.\mathrm{ug} \mathrm{mL}\right)$. Not determined

line earth metals in the sample have no significant effect on the recoveries of the studied metal ions.

The direct atomic absorption spectrometric determinations of some metals can be performed when they are present in high levels in water samples (e.g.. Fe and $\mathrm{Mn}$ in wastewater samples). For this reason. the effects of matrix components in seawater and wastewater samples on the determination of $\mathrm{Cu}(\mathrm{II}) . \mathrm{Pb}(\mathrm{II}) . \mathrm{Cd}(\mathrm{II}) . \mathrm{Cr}(\mathrm{III}), \mathrm{Ni}(\mathrm{II}), \mathrm{Fe}(\mathrm{III}), \mathrm{Mn}(\mathrm{II}), \mathrm{Co}(\mathrm{II})$ and $\mathrm{Bi}(\mathrm{III})$ elements without using the enrichment procedure in the model solutions were also investigated by FAAS. No interference on the elements studied was observed when the concentrations of matrix ions were as follows; $\mathrm{K}^{+} \leq 5000$ $\mathrm{mg} / \mathrm{mL}, \mathrm{Mg}(\mathrm{II}) \leq 5000 \mathrm{mg} / \mathrm{mL}$ (up to $500 \mathrm{mg} / \mathrm{mL}$ for $\mathrm{Bi}(\mathrm{III}$ ) and $1000 \mu \mathrm{g} / \mathrm{mL}$ for $\mathrm{Ni}(\mathrm{II})$ ). $\mathrm{Ca}$ (II) $\leq 1000 \mathrm{mg} / \mathrm{mL}$. and $\mathrm{Na}^{+}$ $\leq 20000 \mathrm{mg} / \mathrm{mL}$. Therefore, the proposed column procedure can be successfully applied to the deternination of trace elements in both salty and wastewaters.

Calibration graph, detection limit, precision and recovery. In the preparation of the calibration standards for $\mathrm{Cu}(\mathrm{II}) . \mathrm{Pb}(\mathrm{II}) . \mathrm{Ni}(\mathrm{II}) . \mathrm{Cd}(\mathrm{II}) . \mathrm{Mn}(\mathrm{II}) . \mathrm{Fe}(\mathrm{III}) . \mathrm{Cr}(\mathrm{III}), \mathrm{Co}(\mathrm{II})$ and $\mathrm{Bi}(\mathrm{III})$. the stock standard solutions of these elements were used by diluting in appropriate ratios with $1.0 \mathrm{M} \mathrm{HCl}$. The standard solutions used for the calibration procedures were prepared before use by dilution of the stock solution with $1.0 \mathrm{M} \mathrm{HCl}$. After determining the optimum preconcentration circumstances, the precision of the method was investigated by using the model solutions containing the spiked elements. The detection limits are commonly defuned as analy te concentration giving a signal equal to three times of standard deviation of blank signals. ${ }^{29}$ The results of the detection limits. the precision, the analytical equations. and the regression data are summarized in Table 3.

The trace metal ions, in concentrations similar to those usually present in the seawater and the wastewater samples. were added to the samples. Then matrix separation and preconcentration procedures were applied. The recoveries of metals for spiked seawater and wastewater samples are given in Table 4 . The high recoveries (>95\%) show the accuracy and validity of the proposed method. Fe(III) and $\mathrm{Mn}$ (II) were not spiked to the wastewater samples due to their high levels allowing to their direct determinations. Therefore. the preconcentration procedure and the recovery
Table 4 . Recoveries (\%) for the spiked elements in seawater and wastewater samples $(\mathbf{n}=3$ )

\begin{tabular}{|c|c|c|c|c|c|}
\hline \multirow{2}{*}{ Element } & \multirow{2}{*}{$\begin{array}{c}\text { Added, } \\
\mu g\end{array}$} & \multicolumn{2}{|c|}{ Seawater } & \multicolumn{2}{|c|}{ Wastewater } \\
\hline & & $\begin{array}{l}\text { Found, } \\
\text { !lg }\end{array}$ & $\begin{array}{c}\text { Recovery } \\
(\%)\end{array}$ & $\begin{array}{c}\text { Found, } \\
\mu \mathrm{g}\end{array}$ & $\begin{array}{c}\text { Recovery } \\
(\%)\end{array}$ \\
\hline \multirow[t]{2}{*}{$\mathrm{Cu}(\mathrm{II})$} & 2.0 & 1.92 & 96 & 1.98 & 99 \\
\hline & 4.0 & $-a$ & - & 4.36 & 109 \\
\hline \multirow[t]{3}{*}{$\mathrm{Pb}(\mathrm{II})$} & 4.0 & - & - & 4.24 & 106 \\
\hline & 8.0 & 8.00 & 100 & - & - \\
\hline & 12.0 & 11.88 & 99 & 11.76 & 98 \\
\hline \multirow[t]{3}{*}{$\mathrm{Ni}(\mathrm{II})$} & 1.0 & 0.96 & 96 & - & - \\
\hline & 2.0 & 1.86 & 93 & 1.92 & 96 \\
\hline & 4.0 & - & - & 4.32 & 108 \\
\hline \multirow[t]{4}{*}{$\mathrm{Cd}(\mathrm{II})$} & 0.4 & 0.416 & 104 & - & - \\
\hline & 0.8 & 0.80 & 100 & - & - \\
\hline & 1.0 & - & - & 0.97 & 97 \\
\hline & 1.6 & 1.63 & 102 & 1.65 & 103 \\
\hline \multirow[t]{2}{*}{$\mathrm{Fe}(\mathrm{III})$} & 1.0 & 1.05 & 105 & - & - \\
\hline & 2.0 & 2.04 & 102 & - & - \\
\hline $\operatorname{Mn}(\mathrm{II})$ & 1.0 & 1.01 & 101 & - & - \\
\hline
\end{tabular}

Not detemined.

studies were not applied to these elements.

Application of the method. We applied the suggested method, finding the concentrations of the trace metal ions investigated in both the seawater with high salinity and the wastewater samples. and the results are given in Table 5. Also. to determine the total metal content of the wastewater sample, the evaporation process was performed by using acid digestion (nitric acid and perclloric acid mixture). ${ }^{32} \mathrm{As}$ can be seen from Table 5, the Pb(II), Ni(II) and Cd(II) levels obtained by means of the suggested method were lower than those of the evaporation method: the $\mathrm{Cu}(\mathrm{II})$. Fe(III) and $\mathrm{Mn}(\mathrm{II})$ concentrations were in good agreement for both methods. Reasons for this may be the $\mathrm{pH}$ variations in sample in which the $\mathrm{pH}$ of the wastewater sample acidified $(\mathrm{pH}$ l) was adjusted to $\mathrm{pH} 9$ before the analysis. Meanwhile, the equilibrium of metal-humic complexes may be established again, and also the rate of equilibrium of metal-humic complexes may be different for each metal. This phenomenon may cause the change of the free metal ion levels in 
Table 5. Element levels obtained by the proposed method for both seawater and wastewater samples (also total metal concentrations obtained by evaporation)

\begin{tabular}{lccc}
\hline & \multicolumn{3}{c}{ Concentration, $\mu g / L^{\sigma}: \bar{x} \pm t \cdot s / \sqrt{n}$} \\
\cline { 2 - 4 } Element & \multicolumn{2}{c}{ Wastewater sample } & Seawater sample \\
\cline { 2 - 4 } & $\begin{array}{c}\text { By the proposed } \\
\text { method }\end{array}$ & By evaporation & $\begin{array}{c}\text { By the proposed } \\
\text { method }\end{array}$ \\
\hline $\mathrm{Cu}(\mathrm{II})$ & $6.96 \pm 1.64(9)^{s}$ & $7.97 \pm 0.51$ & $5.29 \pm 0.60(5)$ \\
$\mathrm{Pb}$ (II) & $10.8 \pm 2.5(9)$ & $41.1 \pm 7.0$ & $1.71 \pm 0.06(4)$ \\
$\mathrm{Ni}(\mathrm{II})$ & $21.1 \pm 2.6(8)$ & $32.8 \pm 2.7$ & $2.05 \pm 0.18(6)$ \\
$\mathrm{Fe}(\mathrm{III})$ & $1264 \pm 70(13)$ & $1530 \pm 115$ & $9.37 \pm 1.63(3)$ \\
$\mathrm{Mn}$ (II) & $217 \pm 17(13)$ & $228 \pm 7$ & $1.34 \pm 0.39(4)$ \\
$\mathrm{Cd}(\mathrm{II})$ & $0.99 \pm 0.82(8)$ & $9.72 \pm 0.75$ & $0.36 \pm 0.03(7)$ \\
\hline
\end{tabular}

"Uncertainty at $95^{\circ} \circ$ confidence level. "Number of replicates.

sample solution to be analyzed. In this case, the rate of equilibrium of metal-humic complexes for the $\mathrm{Pb}$ (II). $\mathrm{Ni}$ (II) and $\mathrm{Cd}(\mathrm{II})$ elements may probably be higher than others investigated.

As can be seen in Tables 3 and 5, all the metal contents found after the preconcentration procedure in the seawater and the wastewater samples are higher than the corresponding limits.

\section{Conclusions}

Solid-phase extraction with Amberlite XAD-16 resin by using HMA-HMDTC reagent as metal chelating agent provides an effective preconcentration and separation procedure for the determination of $\mathrm{Cu}(\mathrm{II}), \mathrm{Pb}$ (II), $\mathrm{Mn}(\mathrm{II}), \mathrm{Cd}(\mathrm{II})$. $\mathrm{Ni}$ (II). and $\mathrm{Fe}$ (III) metals in seawater and wastewater samples. For the analytes of interest, the preconcentration factor was 150 and 75 for the seawater and the wastewater samples. respectively. The proposed procedure is precise, accurate, and a reliable technique for the preconcentration and separation of sone trace heavy metal ions in water samples. such as seawater with high salinity and wastewater.

\section{References}

1. Mizuike. A Entichtmen Techniques for Inorganic Trace Anatysis: Springer-Verlag: Berlin. Heidelberg. New York. 1983: p 2.

2. Elçi. L.: Şahin. U.: Öztaş. S. Talanta 1997. H. 1017.
3. Hiraide, M.; Chen, Z. S.; Kawaguchi, H. And. Sci. 1991. 7.65.

4. Dapaah. A. R. K.: Ayame. A. Anal. Chim. Acta 1998. 360.43.

5. Rodríguez. M. A.: Zambrano. T. A. B.: Ordaz. A. A.: Mendoza. R. N.: Medina. T. I. S. Talanta 1998. 45.875.

6. Kenawy. I. M. M. Hafez. M. A. H.: Akl, M. A.: Lashein. R. R Anal. Sci. 2000. 16. 493.

7. Zhu, W. de Leer. E. W. B.: Kennedy: M.: Alaerts, G. J. F. R. Fresenias J. Anal. Chent 1998.360.74.

8. Tunçeli. A.: Türker. A. R. Anal Sci. 2000. 16.81.

9. Tokal1oğlu. \$.: Kartal. \$.: Elçi. L. Anal. Sci. 2000. 16. 1169.

10. Takahashi, A.: Igarashi. S. Anal Sci. 2000. 16. 433.

11. Tunçeli, A.; Türker. A. R. Analust 1997. 122, 239.

12. Tokalloğlu. \$.; Kartal, \$.: Elçi. L. Mfikrochim. Acta 1997. 127. 281 .

13. Soylak. M.: Elçi. L.: Doğan. M. Anol. Lett. 1997. 30(3). 623.

14. Marques. A. L. B.: Chierice. G. O. J. Braz Chent Soc. 1998. 9. 531 .

15. Anezaki. K:Chen, X: Ogasawara. T: Nukatsuka, I:; Ohzeki, K. And. Sci. 1998. 14. 523.

16. Marczetlko. Z. Separation and Spectrophotometric Determination of Elentents: Ellis Horwood Ltd.: Chichester. 1986: p 107.

17. Shijo. Y: Yoshida. H.: Kitamura. T.: Yoshimoto. E.: Uehara. N. Andl Sci. 1996. 12.761.

18. Pavlovska G.: Stafilov. T.: Cundeva, K. Fresenius J. Anal. Chem. 2001. 36997:8), 670 .

19. Zendelovska. D.: Cundeva. K: Stafilov. T. Mikrochim. Acta 2000. $135(1: 2) .55$.

20. Pavlovska. G.: Stafilov. T.: Cundeva. K. Fresenins J. Anal Chem. 1998. $361(2), 213$.

21. Dapaah. A. R. K. Takano, N.: Ayame. A. And. Chim Acta 1998. $386(3), 281$

22. Pavlovsha. G.: Cundeva. K.: Stafilov. T. Separ. Sci. Technol. 2000. $35(16) .2663$

23. Yamamoto. Y.: Sugita. M.: Ueda. K. Bull. Chem. Soc. Jpn 1982. $55(3) .742$.

24. Ichinoki, S.: Yamazaki. M. Anal Chem 1985. 57(12), 2219

25. Cundeva. K:; Stafilov, T; Pavlovska. G. Ificrochem. J. 2000. $65(2) .165$.

26. Cundeva. K.: Stafilov. T.: Paqlovska. G. Spectrochm. Acta $B$ 2000. 55(7). 1079 .

27. Zendelovska, D.: Pavlovska, G.: Stafilov, T. Talanta 2001, $5+(1)$. 139.

28. Instructions 1fanual: Hitachi Z-8000 Model AAS, Tokyo. 1983.

29. Lajunet1. L. H. T. Spectrochemical Analysis by Atontic Absomption and Entission: Royal Society of Chemistry: Cambridge. 1992: p 9

30. Hiraide. M.: Uchitomi. K. Anal. Sci. 1999. 15. 1051.

31. Tokalioglu, S. Ph. D. Thesis: Erciyes University: Kayseri (Turkey). 1997.

32. Vandecasteele. C. Block. C. B. Modem Hethods for Trace Elentent Deternimation: Iohn Wiley \& Sons Ltd: Chichester. 1997: p 68 . 